\section{Compulsory admission}

For half a century the use of compulsory admission for the mentally ill has steadily declined. In this decline the Mental Health Act of 1959 stands out as a landmark. Its main purpose was to enable as many of the mentally ill as possible to be admitted to hospital as informally as other patients and to ensure that the few who needed treatment but refused it were dealt with quickly, easily, and humanely. This Act in its turn has now come under criticism. Some reformists take the view that civil liberty should be paramount and that no one should be admitted to hospital against his or her will. More cautiously, the Department of Health and Social Security has put out a consultative document, ${ }^{1}$ based mainly on a comparison of suggestions from the Royal College of Psychiatrists ${ }^{2}$ and from MIND (the National Association for Mental Health), ${ }^{3}$ on how the Act should best be amended. The Department held an all-day conference on the document on 25 October. If the more extreme views (including one or two of those put forward by MIND) were adopted there would be more difficulty and delay in getting patients admitted to hospital, and their sufferingincluding that of their relatives-would be intensified. Extra force would then be given to the gibe 4 that the proponents of these views are content to see patients "dying with their rights on."

In a challenging article in the American fournal of Psychiatry, Paul Chodoff ${ }^{5}$ has not been content with defending orthodox psychiatry against such views: he has gone over to the attack. He believes that the rights of the mentally ill to be treated and protected are as important as their civil rights, if not more so, but that the right to treatment is being perilously set aside in favour of freedom. Despite variations in the legal process his analysis-essentially a study of points of view-is wholly transplantable to this side of the Atlantic.

Chodoff distinguishes three viewpoints. The first, the abolitionist, includes those who believe with almost religious fervour that compulsion is never warranted in any circumstance, that liberty is always to be valued above mental health, and that when voluntary compliance with treatment is not forthcoming psychiatrists should withdraw and, if an offence is committed, allow the law to take its course. The abolitionists have included Thomas Szasz, R D Laing, and the several groups of antipsychiatrists. None of the patients described in Chodoff's paper-a severe depressive, a catatonic, a manic, a deluded schizophrenic, and a patient with delirium tremenswould, if unwilling, have received treatment from any of them.

On the other hand all would probably be treated by Chodoff's second group, the medical-model psychiatrists, who would regard such people as ill and would recognise an obligation to treat them with compulsion if necessary. That obligation would not, however, apply to individuals not suffering from mental illness but having instead personality disorders, neurotic reactions, or being dependent on alcohol or other drugs of dependence.

The third viewpoint, that of civil liberties lawyers, does not reject the need on occasion for compulsory admission to hospital. But it does reject the medical model, the notion of psychiatric illness, and the expertise that psychiatrists claim in diagnosis. In rejecting medical criteria this group of lawyers exalt the supposedly more objective estimate of dangerousness "to self or others" as the sole or almost sole ground for using compulsion. Chodoff argues-with clinical evidence on his side-that to concentrate on dangerousness (especially to others) as the sole criterion for involuntary admission to hospital deprives many mentally ill persons of the protection and treatment they urgently require.

Though written by an American lawyer, the MIND report ${ }^{3}$ does not go quite so far as to suggest dangerousness as a sole criterion. Again the medical model is rejected, but "grave disablement," meaning the inability of some mentally disordered people to provide for basic personal needs such as food, clothing, and shelter, is seen as justifying formal admission. The report adds that, although dangerousness and grave disablement are indispensable grounds, there ought also to be additional grounds, such as treatability or lack of insight.

There is an important distinction between dangerousness as used in that context and the special use of the same word in the Butler report ${ }^{6}$ in connection with offenders and reviewable sentences. In considering the need for compulsory admission MIND applies the word to some features in a person's behaviour while mentally ill; in the Butler report it refers to a more or less persistent quality of a person whether mentally disordered or not.

There is one more aspect of compulsory treatment which Chodoff barely mentions. Not only is compulsory admission at risk of becoming more difficult because of a narrowing of criteria: the influence of those he calls the antipsychiatrists and abolitionists is also more pervasive. There have been subtle changes in public opinion, including the opinions of many of the younger doctors. Physical methods of treatment, particularly electroconvulsive therapy and psychosurgery, are under something of a cloud and there are growing suspicions of the side effects of drugs. In consequence, perhaps, too much may be hoped for from psychotherapy for too long because of a reluctance to resort to alternatives. Does delay in treating a manic patient cost him and his family too dear? And how many psychiatrists fail to stand their ground, capitulate, and discharge a patient who, though probably unfit for discharge, has appealed to a mental health review tribunal ?

We in Britain are not yet faced with moral obloquy if the possibility of compulsory admission is considered (as is the case in some places in the United States), but perhaps we should stop patting ourselves on the back over how few shortterm patients need to be compulsorily admitted. Perhaps there should be more.

\footnotetext{
${ }^{1}$ Department of Health and Social Security, A Review of the Mental Health Act, 1959. London, HMSO, 1976.

2 Public Policy Committee, British fournal of Psychiatry, supplement, News and Notes, 1974, 125, (Oct and Nov).

${ }^{3}$ Gostin, L O, A Human Condition, vol I. Leeds, MIND (National Association for Mental Health), 1975.

4 Treffert, D A, American Fournal of Psychiatry, 1973, 130, 1041.

5 Chodoff, P, American fournal of Psychiatry, 1975, 133, 496.

${ }^{6}$ Report of the Committee on Mentally Abnormal Offenders, (Cmnd 6244). London. HMSO, 1975
}

\section{Brain death}

Few medical topics have provoked more public comment than the definition of brain death, but it is also true that few subjects have been more confused by muddled thinking and inadequate expert advice. The need for clinical criteria for the diagnosis of brain death has come from the wide availability of intensive care techniques. It is now routine practice for patients with some kinds of respiratory failure to be maintained on a ventilator, and inevitably many do not recover. The decision to stop ventilation that has to be taken in such cases has 